\title{
Environmental Protection and Oil and Gas Production IN THE NOVA SCOTIA OFFSHORE: A GUIDELINES APProach TO OPERATIONAL Discharges
}

\author{
MIKIS MANOLIS
}

\begin{abstract}
This article examines and describes the regulatory framework governing the production of oil and gas in the Nova Scotia offshore. Specific attention is given to the ecological dangers posed by operational discharges into the marine environment by the oil and gas industry. The regulation of operational discharges under the Canada-Nova Scotia Offshore Petroleum Resources Accord Implementation Act and the role of guidelines in this regard is discussed. It is argued that the altempted use of guidelines by the Canada-Nova Scotia Offshore Petroleum Board to impose binding requirements on operators is beyond its statutory authority. The administrative problems associated with these "mandatory" guidelines are also discussed.
\end{abstract}

Cet article examine et décrit le cadre législatif et réglementaire gouvernant la production de pétrole et de gaz au large de la Nouvelle-Écosse. Une attention toute particulière est portée aux dangers écologiques que posent les déversements opérationnels de l'industrie du pétrole et du gaz dans l'environnement marin. Les règlements portant sur les déversements opérationnels sont discutés aux termes de la Mise en oeuvre de l'Accord Canada Nouvelle-Écosse sur les hydrocarbures extracôtiers et le rôle des directives à cet égard. Le raisonnement soutient que la tentative d'utiliser les directives de l'Office Canada - Nouvelle-Écosse des hydrocarbures extracôtiers pour imposer aux opérateurs des exigences contraignantes dépasse les dispositions législatives habilitantes de celui-ci. Les problèmes associés à ces directives "obligatoires" sont également discutés.

\section{TABLE OF CONTENTS}

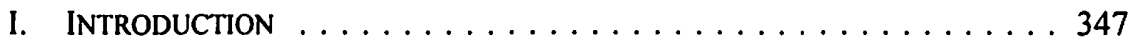

II. A REGULATORY FRAMEWORK:

THE CNSOPB AND ENVIRONMENTAL HARMS ......... 349

III. ENVIRONMENTAL PROTECTION:

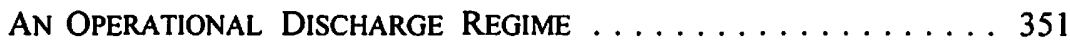

A. REGULATIONS AND THE ROLE OF GUIDELINES

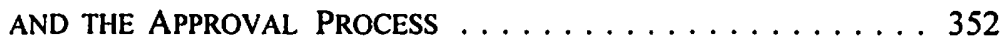

B. GUIDELINES AND ENVIRONMENTAL

MANAGEMENT SYSTEMS . . . . . . . . . . . . . . 354

IV. A QUASI-REGULATORY GUIDELINES APPROACH:

LEGAL UNCERTAINTY AND ADMINISTRATIVE PROBLEMS . . . . 357

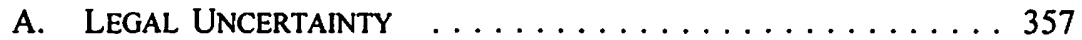

B. AdMInISTRATIVE Problems $\ldots \ldots \ldots \ldots \ldots \ldots \ldots \ldots$

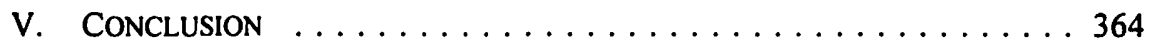

\section{INTRODUCTION}

Nova Scotia's offshore petroleum industry began in the late 1950s with exploration in the Sable Island area. Actual production started in 1992 with the Cohasset-Panuke offshore oil field, which in 1998 produced 1.1 million cubic metres of oil. In 1999 the Sable Offshore Energy Project began producing natural gas for Canadian and

Associate, Campney \& Murphy, Barristers and Solicitors, Vancouver, British Columbia. 
northeastern American markets. The six fields under development in the Sable Project are expected to yield 99.1 billion cubic metres of natural gas.' Today, this growing industry is governed by a legal regime that bears little resemblance to the legislation of the Trudeau-era National Energy Program with legislative lacunae and broad ministerial discretion. ${ }^{2}$ Nowadays, the unconstitutional uncertainties over offshore hydrocarbon jurisdiction and the hostile intergovernmental conflict that characterized the 1979 to 1985 period have been largely resolved, or at least muted by the accords entered into by the provinces of Nova Scotia and Newfoundland with the federal government. ${ }^{3}$ These accords were established by two sets of mirror legislation, often referred to as the Accord Acts. ${ }^{4}$

The Accords Acts established two Boards to act as the primary regulatory agencies and focal points for oil and gas activities in their respective areas, namely the CanadaNova Scotia Offshore Petroleum Board [hereinafter the CNSOPB or the "Board"] and the Canada-Newfoundland Offshore Petroleum Board. ${ }^{5}$ As Osborn J. of the Newfoundland Supreme Court noted in Saint John's (City) v. Canada-Newfoundland Offshore Petroleum Board, ${ }^{6}$ the legislative framework governing the exploration and development of the East Coast offshore area is the product of many years of discussion and negotiation and establishes a carefully constructed joint management scheme that allocates particular areas of responsibility and authority between governments and the Board. ${ }^{7}$ The purpose of this article is to examine the approach taken by the CanadaNova Scotia Offshore Petroleum Board under the legislative framework established by the Accord Act towards environmental protection. In this regard, a particular emphasis is placed on operational discharges and associated environmental management systems.

Petroleum Communication Foundation, Petroleum Industry - Fast Facts: Nova Scotia (Calgary: Petroleum Communication Foundation, 1999).

$2 \quad$ D. Black \& F.V.W. Penick, "Survey of Legal Issues: Canadian Offshore Oil and Gas" (1991) 30 Alta. L. Rev. 178 at 179.

$3 \quad$ Ibid. at 179-82. While the intergovernmental litigation and conflict that formed the backdrop of these agreements is beyond the scope of this article, it should be recognized that the accords and the resulting legislation have significant constitutional overtones. On this subject, see A. Chircop, "Canada: Federal v. Provincial Offshore Jurisdiction: Reference Re the Seabed and Subsoil of the Continental Shelf Offshore Newfoundland" (1984-85) 3 Oil \& Gas L. \& Tax. Rev. 51; E.A. Fitzgerald, "The Newfoundland Offshore Reference: Federal-Provincial Conflict over Offshore Energy Resources" (1991) 23 Case W. Res. J. Int'l L. 1; and T.L. McDorman, "Canadian Offshore Oil and Gas: Jurisdiction and Management Issues in the 1980s and Beyond" in D. McRae \& G. Munro, eds., Canada's Oceans Policy: National Strategies and the New Law of the Sea (Vancouver: University of British Columbia Press, 1989).

See Canada-Nova Scotia Offshore Petroleum Resources Accord Implementation Act, S.C. 1988, c. 28 [hereinafter the Accord Act or the Nova Scotia Accord Act]; Canada-Nova Scotia Offshore Petroleum Resources Accord Implementation Act, S.N.S. 1987, c. 3. Section references will refer to the federal version of the Accord Act; and Canada-Newfoundland Atlantic Accord Implementation Act, S.C. 1987, c. 3 [hereinafter the Newfoundland Accord Act]; CanadaNewfoundland Atlantic Accord Implementation Act, S.N. 1986, c. 3.

See Black \& Penick, supra note 2.

[1998] N.J. No. 233 (T.D.), online: QL (NJ).

Ibid. at para. 95 . 
To this end, this article is divided into three parts. The first section briefly describes the general regulatory framework governing the development of petroleum resources in the Nova Scotia offshore area and describes the ecological dangers posed by operational discharges into the marine environment. The second section provides a descriptive analysis of the operational discharge regime established under the Accord Act. The regulations and the role of guidelines and the activity approval process are examined. Emphasis is placed on two guidelines in particular, the Offshore Waste Treatment Guidelines ${ }^{8}$ and the Guidelines Respecting the Selection of Chemicals Intended to be Used in Conjunction with Offshore Drilling \& Production Activities on Frontier Lands. ${ }^{9}$ In this respect, the role of environmental management systems is explored. The third and final section examines the legal and administrative difficulties posed by the Board's quasi-regulatory approach to the use of guidelines as they relate to operational discharges.

\section{A REgUlatory FRAMEWORK: THE CNSOPB AND ENVIRONMENTAL HARMS}

In simple terms, the regulatory framework governing the development of oil and gas in the Nova Scotia offshore area is comprised of the Accord Act, associated regulations, and the guidelines and policies issued by the Canada-Nova Scotia Offshore Petroleum Board (CNSOPB). The CNSOPB, established under the Accord Act in 1990, is the principal regulatory agency in respect of offshore petroleum activities in Nova Scotia's offshore area. The CNSOPB is an independent joint agency of the Canadian and Nova Scotian governments responsible for, among other things, the enhancement of safe working conditions for offshore operations, management and conservation of offshore resources, and protection of the environment during offshore petroleum activities. ${ }^{10}$ To fulfill its mandate with respect to environmental protection, the Board must deal with, inter alia, the potential environmental harms associated with the offshore petroleum development in general and the specific dangers posed by the actual production processes.

The specific ecological dangers associated with offshore oil and gas development derive from both accidental and systemic operational events. Accidental events with potentially significant environmental harms are well blow-outs" and oil spills from offshore platforms and transport vessels. Systemic events generally involve operational

$\mathbf{x}$ with Offshore Drilling \& Production Activities on Frontier Lands (Halifax: CNSOPB, 1999), online: CNSOPB <www.cnsopb.ns.ca/Regframework/chemicalguidelines.pdf> [hereinafter Chemical Selection Guidelines].

10 See CNSOPB, "CNSOPB Overview," online: CNSOPB < www.cnsopb.ns.ca/Generalinfo/general. html> (date accessed: 18 July 2002).

1 "A well blow-out occurs when there is a loss of well control resulting in uncontrolled hydrocarbon emissions." Meltzer Research \& Consulting, Historical Overview of Offshore Oil and Gas Development: Case Studies of the North Sea and the Gulf of Mexico (Halifax: Meltzer Research \& Consulting, 1998) at UK-19. In general, such occurrences are quite rare. For instance, there has never been a blow-out in the UK sector of the North Sea. 
discharges, which include drill cuttings and solids, sour gas wastes, deck drainage, cooling water, produced water, produced sand, drilling muds and related chemicals, ${ }^{12}$ storage displacement water, bilge and ballast water, and other routine discharges such as human-based waste and garbage. ${ }^{13}$

Among operational discharges, particular emphasis is often placed on drill cuttings, drilling muds and produced water. ${ }^{14}$ Drill cuttings or solids are particles that are generated by drilling into subsurface geological formations and carried to surface with drilling muds. Drill solids are themselves generally oil-laden. ${ }^{15}$ The discharge or deposition of drill cuttings at sea has the potential to significantly affect benthic organisms and the community structure of seabed fauna by smothering and contaminating these organisms. ${ }^{16}$ Produced water is oil-laden water, which is extracted during the production process and includes formation water, injection water and process water. ${ }^{17}$ The environmental impact of produced water is an emerging issue in offshore production as it often contains relatively high concentrations of metals, such as barium, beryllium, cadmium, chromium, copper, iron, lead, nickel, silver and zinc. ${ }^{18}$ Drill muds are circulating fluids (oil or water-based) used to clean and condition the well, lubricate the drill bit and counterbalance formation pressure. ${ }^{19}$

These oil-laden wastes receive varying degrees of treatment before being discharged into the marine environment. ${ }^{20}$ The discharge of these wastes into the marine environment may kill or produce harmful sublethal effects in marine organisms, alter the ecosystem and cause component metal and organic compounds to accumulate in marine organisms to such concentrations that these organisms and their consumers, including humans, suffer acute, chronic and sublethal effects. ${ }^{21}$ Clearly, an effective environmental protection regime in the offshore must address these concerns.

Other well treatment fluids used in well workover, stimulation and completion processes and formation fracturing operations often contain diesel oil or other highly aromatic oils or may be strongly acidic. Waste Treatment Guidelines, supra note 8 at 8. Air emissions resulting from flaring and venting may also be considered part of this category. D. Jin \& T.A. Grigalunas, "Environmental Compliance and Offshore Oil and Gas Exploration and Production" in K. Sherman, H. Kumpf, \& K. Steideger, eds., The Gulf of Mexico Large Marine Ecosystem: Ecology, Sustainability and Management (New York: Blackwell Scientific Publications, 1999) 635.

Waste Treatment Guidelines, supra note 8 at 6.

Corporate Watch, "The Oil and Gas Industry," online: Corporate Watch <www.corporatewatch.org/ publications/pollution.html> (date accessed: 18 July 2002). This potential may be mitigated by reinjecting the drill solids into dedicated disposal wells. Waste Treatment Guidelines, ibid. at 6-7. Waste Treatment Guidelines, ibid. at 5.

Ibid. Meltzer, supra note 11 at UK-23.

Waste Treatment Guidelines, ibid. at 5-6.

See generally Jin \& Grigalunas, supra note 14.

Ibid. at 635. 


\section{Environmental Protection: AN Operational Discharge Regime}

The CNSOPB's responsibility for environmental protection extends to each phase of offshore petroleum development, from initial exploration to final abandonment and termination of the project. ${ }^{22}$ To carry out its environmental protection responsibilities with respect to operational discharges during production, the Board relies primarily on components of its legislative base, authorizations approvals and two guidelines in respect of the minimum standards for offshore operators, specifically the Waste Treatment Guidelines ${ }^{23}$ and the Chemical Selection Guidelines. ${ }^{24}$ Because produced water, drill cuttings, solids and muds are oil-laden, such operational discharges are, in a generic sense, controlled under the "spills" provisions of the Accord Act. Section 166(1) of the Accord Act states that "[n]o person shall cause or permit a spill on or from any portion of the offshore area." "Spill" in this context is defined as a "discharge, emission or escape of petroleum, other than one that is authorized under the regulations or any other federal law or that constitutes a discharge from a ship to which Part XV of the Canada Shipping Act or Part 6 of the Marine Liability Act applies."25 Therefore, it would seem highly likely that unauthorized petroleum-laden discharges in the form of drill cutting or muds would be covered by the prohibition in this section.

Sanctions for a violation of this provision are provided for in s. 199(1)(a), which establishes that a contravention of that Part of the Accord Act is an offence punishable "(a) on summary conviction, to a fine not exceeding one hundred thousand dollars or to imprisonment for a term not exceeding one year, or to both; or (b) on conviction on indictment, to a fine not exceeding one million dollars or to imprisonment for a term not exceeding five years, or to both." ${ }^{26}$ While some small spills have occurred in the Nova Scotia offshore area, prosecutions under the "spills" provisions of the Accord Act have not yet taken place. ${ }^{27}$ Though the potential for prosecution exists, the Board has chosen to adopt a consultative co-operative process when responding to instances of non-compliance with prosecution only being considered as a last resort. In light of this approach, the primary manner in which the CNSOPB fulfills their environmental responsibilities is by linking the issuance of offshore development authorizations to the satisfactory submission of general and specific work plans.

CNSOPB, "Environmental Protection," online: CNSOPB <www.cnsopb.ns.ca/Generalinfo/envir overview.html> (date accessed: 18 July 2002) [hereinafter "Environmental Protection"].

Waste Treatment Guidelines, supra note 8 at 10.

"Environmental Protection," supra note 22 at 1.

Accord Act, supra note 4, s. 165(1).

Ibid., s. 199(2). Under ss. 66-70 of the Accord Act, spills must be reported to the Chief Conservation Officer who will have broad emergency powers including the authority to take over the management and control of the project to contain, reduce or mitigate the environmental dangers caused by the spill.

Department of Fisheries and Oceans, Eastern Scotian Shelf Integrated Management (ESSIM)

Project: Overview and Use Audit (Dartmouth: Oceans Act Coordination Office, 1999) at 3.10. 
VOL. $40(2) 2002$

\section{A. Regulations AND THE ROLE OF Guidelines aNd THE APPROVAl Process}

Before carrying out any work or activity in the offshore area, an operator must be authorized to do so by the Board. ${ }^{28}$ In order to develop a pool or field, an operator must obtain both general and specific authorizations. The first phase of this process is the Development Plan Application. ${ }^{29}$ Under the Accord Act, a development plan must include, to the level of detail as may be prescribed by the Board, inter alia, a description of the "environmental factors in connection with the proposed development." ${ }^{30}$

To this end, the Board requires that a Development Plan Application consist of a Development Plan, A Canada-Nova Scotia Benefits Plan, and an Environmental Impact Statement (EIS). ${ }^{31}$ The Environmental Impact Statement is to be produced with sufficient detail to satisfy the requirements of a Comprehensive Study under the Canadian Environmental Assessment Act. ${ }^{32}$ This is primarily because the Canadian Environmental Assessment Act Comprehensive Study Regulations include oil and gas projects under Part IV. ${ }^{33}$ As a result, the EIS should include, among other things, the identification of environmental impacts of the project and the measures that are technically and environmentally sound to mitigate any significant adverse effects of the project or, in other words, an environmental protection plan (or the beginnings thereof). Under the Accord Act, an approved development plan is a precondition for all specific work authorization. ${ }^{34}$

Generally speaking, approval of the Development Plan signifies that the proponents have been granted approval for their general development approach and may apply for specific activity authorizations, including authorizations to drill wells, install production facilities and pipelines, and begin production. ${ }^{35}$ Section 142 of the Accord Act confers upon the Board the authority to issue authorizations in respect of each activity to be carried on in the offshore area and allows the Board to subject such authorizations to such requirements or conditions "as the Board determines or as may be prescribed." 36 With respect to operational discharges, the most significant work authorization is the "production operations authorization."

Ibid.

See CNSOPB, Guidelines on Plans and Authorizations Required for Development Projects (Halifax: CNSOPB, 1995) [hereinafter Development Plan Guidelines].

Accord Act, supra note 4, s. 143(3)(a)(ii).

Development Plan Guidelines, supra note 29 at 2-11.

Canadian Environmental Assessment Act, S.C. 1992, c. 37 [hereinafter CEAA].

It should be noted that the EIS does not replace the requirement under $C E A A$. The standards of the $C E A A$ are merely adopted to promote consistency and avoid inter-agency conflict. See CNSOPB, Environmental Assessment Policy, No. 3154.008 (27 June 1996), online: CNSOPB <www.cnsopb.ns.ca/Environment/assessment.html> (date accessed: 18 July 2002).

Accord Act, supra note 4, s. 143(1).

CNSOPB, "Canada-Nova Scotia Offshore Petroleum Board Approves Sable Offshore Energy Project Benefits Plan and Development Plan" (30 December 1997), online: CNSOPB <www.cnsopb.ns.ca/Press_Releases/press12-30-97.html> (date accessed: 18 July 2002).

Accord Act, supra note 4, s. 142(4). 
Pursuant to s. 51(2) of the Nova Scotia Offshore Area Petroleum Production and Conservation Regulations, ${ }^{37}$ an operator ${ }^{38}$ must "develop and submit to the Chief Conservation Officer ${ }^{[39]}$ an environmental protection plan that provides for the protection of the natural environment."40 According to the Regulations, a productions operations authorization is subject, inter alia, to the requirement that "an environmental protection plan exists." ${ }^{\prime \prime}$ In general terms, the environmental protection plan (EPP) is a manual containing an detailed outline of the operational strategies which the operator will follow to minimize or mitigate the environmental effects of the project and provide guidance on how to implement these strategies. ${ }^{42}$ The EEP must include a description of the program established to monitor and the measures adopted to minimize or mitigate the effect on the natural environment of routine operations; contingency plans for response and mitigation of oil and hazardous substance spills; a description of procedures and equipment for handling and disposing of waste material; a summary of chemical substances intended for use; and plans for environmental restoration of the production site following termination of production. ${ }^{43}$

Most importantly, an EPP must include compliance monitoring programs to ensure that the composition of spilled waste material is within the limits specified in the EPP. In addition, s. 49(1) obliges an operator to ensure that "all waste material produced and stored at a production site is treated, handled and disposed of in accordance with the environmental protection plan."44 It is imperative to note, however, that these regulations do not specify limits with respect to the composition of disposed waste materials. The regulations merely state that the "Chief Conservation Officer shall approve the environmental protection plan ... where adherence to the plan will provide for the protection of the natural environment." 45 To date, there are no specific regulations dealing with operational waste treatment and pollution. ${ }^{46}$

In this context, the main tool used by the Board for securing satisfactory operational practices has been to issue guidelines to establish the minimum standards of the discharge regime. Section 156 of the Accord Act authorizes the Board to issue guidelines with respect to the application and administration of s. 142 (authorizations) and the regulations made pursuant to s. 153 (protection of the environment and production). As discussed below, these guidelines generally determine the content of

Nova Scotia Offshore Area Petroleum Production and Conservation Regulations, N.S. Reg. 144/96 [hereinafter Production Regulations].

An "operator" is defined as "a person who has applied for or has been issued a production operations authorization or has applied for or has been granted an approval for a development plan." See Production Regulations, ibid., s. 2(1)(dd).

The Chief Conservation Officer is chief executive officer of the Board. See Accord Act, supra note 4, s. 144.

Production Regulations, supra note 37, s. 51(2).

Ibid., s. 8(2).

Development Plan Guidelines, supra note 29 at A-17.

Production Regulations, supra note 37, s. 51(2).

Ibid., s. 49(1).

lbid., s. 51(5).

As will be seen below, this lack of regulations may be the source of significant enforcement difficulties. 
the conditions of an authorization issued pursuant to s. 142 of the Accord Act. Section 142(5) of the Act gives the Board the discretion to revoke or suspend an operating licence or an authorization for failure to comply with a requirement or condition to which the licence or authorization was issued. Section 199(1)(e), in turn, makes it an offence to undertake or carry on a work or activity without an authorization under paragraph $142(1)(b)$ or without complying with the approvals or requirements of such an authorization. ${ }^{47}$

\section{B. Guidelines and Environmental Management Systems}

The two principal guidelines dealing with operational discharge are the Waste Treatment Guidelines and the Chemical Selections Guidelines. As the Board specifically indicates with respect to the Waste Treatment Guidelines, it is the Board's "intention that such authorizations will normally be subject to conditions ... that will be in accordance with these Guidelines." ${ }^{48}$ This linkage was unequivocally made in Condition 15 of the Board's Development Plan Decision Report of the Sable Offshore Energy Project. ${ }^{49}$ Condition 15 mandates that, in addition to complying with the applicable promulgated regulations, "[t]he Proponents shall also comply with any draft regulations, standards, and guidelines that may be developed in the future and adopted by the Board." In addition, Condition 15 states that "[s]uch draft regulations, standards or guidelines may be revised from time to time and, if adopted by the Board, the revised version shall apply and shall supersede any earlier versions."

In relation to operational discharges, the Waste Treatment Guidelines identify specific discharge concentrations to be achieved by operators before disposal:

Produced Water: Dispersed Oil Content - $40 \mathrm{mg} / \mathrm{L}$

Drilling Muds - Water-Based: No Treatment Necessary

Synthetic-Based: Preferred to Oil-Based Mud - Shore Transfer

Oil-Based: If Approved: Max. 5\% Aromatic Oil - Shore Transfer

Drill Solids - If Reinjection Not Feasible: Oil Concentration - $15 \mathrm{~g} / 100 \mathrm{~g}$

Storage Displacement Water: Oil Concentration - $15 \mathrm{mg} / \mathrm{L}$

Bilge and Ballast Water: Oil Concentration $-15 \mathrm{mg} / \mathrm{L}$

Deck Drainage: Oil Concentration - $15 \mathrm{mg} / \mathrm{L}$

As will be seen below, this approach, while it may be an effective tool with respect to satisfying the initial or preparatory requirements of environmental protection, does not provide an adequate basis for the enforcement of the minimum standards outlined.

Comparison of the Development Plan Guidelines with the appended Development Plan Requirements clearly confirms and actualizes this intention. See Development Plan Guidelines, supra note 29. 
Well Treatment Fluids: Oil Concentration - $40 \mathrm{mg} / \mathrm{L}$

Cooling Water: Possible Restrictions as to Residual Chlorine Level ${ }^{52}$

Pursuant to the Waste Treatment Guidelines, operators "should design compliance monitoring programs which provide for the measurement and reporting of waste discharges." ${ }^{3}$ Compliance monitoring programs "should also provide, where practicable, for the measurement or the calculation of absolute quantities of oil and other waste contained in discharges." ${ }^{4}$ In addition to compliance monitoring programs, operators are pressed to "design and implement environmental effects monitoring programs to detect and document any adverse environmental effects which may result from their operations." $"$ The results of the compliance monitoring programs and environmental effects monitoring programs are to be used by regulatory authorities, in consultation with industry and other interested parties, to determine the continued adequacy of the waste treatment and disposal procedures used to achieve the waste discharge concentrations cited in the Guidelines. ${ }^{56}$ Both compliance monitoring programs and EEM programs require the approval of the Chief Conservation Officer. ${ }^{57}$

Like the Waste Treatment Guidelines, the Guidelines Respecting the Selection of Chemicals Intended to be Used in Conjunction with Offshore Drilling \& Production Activities on Frontier Lands ${ }^{58}$ establish permissible concentrations for ocean disposal and toxicological ratings to determine whether, if at all, chemicals may be disposed of at sea. ${ }^{59}$ To this end, the Chemical Selection Guidelines oblige an operator to establish, as part of his or her management system, a rigorous chemical selections procedure that is either identical to or consonant with the procedures outlined in the Guidelines. ${ }^{60}$ Moreover, the Chemical Selection Guidelines suggest that operators consider "developing environmental effects monitoring (EEM) programs to detect and document any adverse environmental effects which may result from the discharge of chemicals to the marine environment." ${ }^{16}$ The results are to be used by regulatory authorities, in consultation with industry and other interested parties, to aid in determining whether or not the Chemical Selection Guidelines are achieving the declared environmental protection objectives. ${ }^{62}$ Such an EEM program may be specific

This listing is for illustrative purposes only and is by no means comprehensive. See Waste Treatment Guidelines, supra note 8 at 10.

Ibid.

Ibid.

Ibid.

Ibid.

Production Regulations, supra note 37, s. 51(2).

Chemical Selection Guidelines, supra note 9 at 6-7.

Ibid. at 9-22. These guidelines are of substantial importance in that the Canadian Environmental Protection Act provisions dealing with ocean disposal (Part VI) do not apply to any discharge that is incidental or derived from the exploration, exploitation and offshore processing of seabed mineral resources. See ibid. at 6; B.B. de Jonge, Law of Pollution and Debris from Oil and Gas Drilling and Production Operations Offshore Nova Scotia (LL.M. Thesis, Dalhousie Law School 1998) at 58.

Chemical Selection Guidelines, supra note 9 at 6.

Ibid. at 9.

Ibid. 
to the discharge of chemicals into the marine environment or form part of a larger EEM program developed for the operation as a whole. ${ }^{63}$

On the whole, the regulatory approach taken by the CNSOPB with respect to operational discharges and environment protection is one in which heavy reliance is put on the operator to put in place an internal environmental management system to ensure compliance with the applicable regulations, authorizations conditions and guidelines. ${ }^{64}$ In the aggregate, many of the components of this regime satisfy the basic requirements of the ISO 14001 standard for environment management systems. For instance, the envisioned EPPs and EEM programs appear to fulfill the requirements for environmental planning, monitoring, corrective action, operational control, emergency preparedness and environmental management system auditing. ${ }^{65}$ In this regard, the EPP submitted by Sable Offshore Energy Incorporated with its Development Plan Application clearly embodies most, if not all, of the specifications developed in ISO

63 In addition to these environmental management/monitoring system requirements, specific activity authorizations are subject to the satisfactory submission of a "certificate of fitness" in relation to the equipment, installations, production and accommodation facilities. The certificate of fitness is significant from an environmental-protection perspective in that its issue is dependent on whether or not the components covered can function without polluting the environment. Pursuant to $s$. 8(2)(a) of the Production Regulations, a certificate of fitness in respect of the production installation must be issued before a production operations authorization may be granted. A "certificate of fitness" is defined as a "certificate, in the form fixed by the Board, issued by a certifying authority in accordance with s. 4 of the Nova Scotia Offshore Area Certificate of Fitness Regulations." These regulations (Nova Scotia Offshore Area Certificate of Fitness Regulations, N.S. Reg. 4/96) designate four maritime classification societies as certifying authorities that an operator is permitted to use, specifically the American Bureau of Shipping, Bureau Veritas, Det Norske Veritas Classification A/S or Lloyd's Register of Shipping. Section 4 of the Certificate of Fitness Regulations stipulates, inter alia, that a certifying authority may issue a certificate of fitness in respect of a production installation if it determines that the installation is designed, constructed, transported and installed in accordance with the applicable regulations and is "fit for the purpose for which it is to be used and can be operated safely without polluting the environment." In addition to obtaining a certificate of fitness, an operator must submit a Declaration of Operator for all offshore activities. This Declaration is signed by a senior officer of the operator who avows that the equipment is fit for the purpose and the personnel operating it are properly trained such that the activity can be undertaken safely without polluting the environment. See Accord Act, supra note 4, ss. 143.1 and 143.2; Production Regulations, supra note 37, ss. 2(1)(f) and 2(1)(g); Nova Scotia Offshore Area Certificate of Fitness Regulations, N.S. Reg. 4/96, ss. 2 and 4.

(4 Department of Fisheries and Oceans, supra note 27 at 3.10. In this vein, one of the stated objectives of Chemical Selections Guidelines is the development of an industry-driven system that can be audited by the regulatory community. A corollary of this objective is the goal of developing a regulatory system that achieves the maximum benefit with the least amount of effort and cost to both the industry and the regulator. See Chemical Selections Guidelines, supra note 9 at 3-4. In a sense, this regulatory regime mandates what Michael Ray Harris refers to as a "comprehensive environmental auditing program" in that it embodies a system of policies and procedures for achieving compliance with the applicable laws and mandates. See M.R. Harris, "Promoting Corporate Self-Compliance: An Examination of the Debate Over Legal Protection for Environmental Audits" (1996) 23 Ecology L.Q. 663 at 671.

is See International Organization for Standards, Draft International Standards: ISO/DIS 1400I, ISO/TC 207/SC 1 at 7-20. 
14001 , from the development of corporate environmental policy to the "continuous" improvement of environmental management. ${ }^{66}$

While there are complementary incentives, such as the avoidance of liability through the establishment of a due diligence defence, ${ }^{67}$ and motivating the establishment of the internal management systems contemplated by this regime, it is important to note that these systems and procedures are mandated by the Board through its guidelines. Should the Board as a result of its own assessment procedures, such as formal audits and site inspections, find an internal environmental management system to be flawed, the potential exists for the Board to resort to an activity authorization suspension or prosecution. ${ }^{68}$ There are, however, certain difficulties with the Board's technique of linking its guidelines to the conditions it attaches to authorizations approvals that make the Board's resort to such sanctions problematic under the Accord Act. These difficulties put the Board's ability to enforce the conditions of its authorizations and, by extension, the procedural components and substantive standards of the Waste Treatment and Chemical Selections Guidelines at issue. These problems are both legal and administrative in nature.

\section{A QUASI-REgUlatoRY GUIDELINES APPROACH: Legal UnCertainTy and administrative Problems}

\section{A. LEGAL UNCERTAINTY}

Foremost among the difficulties associated with the Board's technique of linking its guidelines to the conditions it attaches to authorizations approvals is that it is of dubious legality. More specifically, it could be argued that the CNSOPB is, by creating a clear linkage between the content of its guidelines and the conditions of the authorizations it issues, creating a de facto legislative scheme, which is beyond its statutory authority. In other words, the Board's guidelines approach to operational discharge may be ultra vires the Accord Act. The issue of the statutory authority of the Offshore Boards to impose binding requirements in the absence of specific regulation was, in part, addressed by the Trial Division of the Newfoundland Supreme Court in relation to a Drilling Program Authorization in Petro-Canada v. Canada-Newfoundland Offshore Petroleum Board. ${ }^{69}$

In this case, the applicant, Petro-Canada, submitted that the Newfoundland Offshore Petroleum Board did not have jurisdiction under the Canada-Newfoundland Atlantic

Exxon Mobil, Sable Project: Development Plan Application, vol. 3, online: Exxon Mobil $<$ www.soep.com/cgi-bin/getpage?pageid=1/15/0\&dpa=3/8/3/1> (date accessed: 18 July 2002). Compare with International Organization for Standards, supra note 65. general discussion of the potential requirements of due diligence defence with respect to the Accord ACt is beyond the scope of this article. Nevertheless, please refer to de Jonge, supra note 59 at $61-76$. 
Accord Implementation $A c t^{70}$ to impose a condition, pursuant to draft drilling regulations, requiring formation flow tests. ${ }^{71}$ The condition imposed specifically obliged the operator to comply with the draft regulations and "all modifications and amendments thereto as may be promulgated from time to time."72 Justice Barry, in rejecting Petro-Canada's submission, held that s. 133(1)(b) of the Newfoundland Accord $A c t$, which entitled the Board "to authorize, in its discretion, 'such requirements ... as the Board determines or as may be prescribed',"73 was broad enough to permit the Board to incorporate the draft regulations as conditions by reference. This section is clearly consonant with s. 142(4) of the Nova Scotia Accord Act, which states that "[a]n authorization is subject to such approvals as the Board determines or as may be granted in accordance with the regulations and such requirements and deposits as the Board determines or as may be prescribed." 74 This holding, therefore, might be seen as an ostensible approval of the CNSOPB's technique of making compliance with promulgated guidelines a condition of authorizations approvals. This decision, however, does not resolve this issue categorically.

First, Barry J.'s decision applied to a legislative context that is different from that which exists presently under both the Newfoundland and Nova Scotia Accord Acts. More specifically, it could be argued that the subsequent amendment of the legislation necessitates a different interpretation of the Board's authority. As Barry J. noted in Petro-Canada, "[t]he subsequent amendment of the legislation to authorize the ... Governor in Council to incorporate such standards or specifications by reference in regulations may require a different interpretation of the Board's authority under the present section 134 (the former 133)." 75 The amended legislation was, however, not at issue in the case at bar and Barry J. declined to address this point further. ${ }^{76}$

In a manner similar to that of the amended Newfoundland Accord Act, s. 153 of the present Nova Scotia Accord Act authorizes the Governor in Council" to incorporate by reference "the standards or specifications of any government, person or organization" when making regulations in relation to the production of petroleum resources and environmental protection. ${ }^{78}$ Clearly, a strong argument could be made asserting that expressly conferring upon the Governor in Council the authority to incorporate such standards by reference implies a clear limitation on the Board's authority to incorporate by reference the standards of other parties as binding requirements, particularly in light of the fact that the Board is not granted similar authority and those standards it is attempting to incorporate are its own.

711 S.N. 1986, c. 37.

$7 \quad$ Supra note 69 at 229.

72 Ibid.

$" \quad$ lbid. at 230.

7 Accord Act, supra note 4, s. 142(4).

75 Supra note 69 at 230.

Ibid.

"According to s. 2 of the Accord Act, supra note 4, the Governor in Council is the "Federal Government."

78 Accord Act, supra note 4, ss. 153(1) and 153(2). 
This argument could be met with an assertion that the wording of s. 142(4), like s. 133 of the former Newfoundland Accord Act, clearly contemplates the imposition of requirements other than those that have been prescribed by regulation. Indeed, the wording of s. 142(4) appears to support this assertion. As noted above, s. 142(4) provides that "an authorization is subject to such approvals as the Board determines or as may be granted in accordance with the regulations and such requirements ... as the Board determines or as may be prescribed." ${ }^{79}$ Under s. 2 of the Accord Act, "prescribed" means "prescribed by regulations made by the Governor in Council." While this distinction would seem to support the Board's authority to impose some type of requirement distinct from those prescribed in regulation, it does not necessarily follow that the Board can justifiably make compliance with its guidelines, in particular those relating to operational discharges, a condition of the authorizations it approves.

First, the Board appears to lack the requisite statutory authority to establish and promulgate, at its owns behest, a substantive regime applicable to such discharges. In this regard, it is essential to note that s. 153(1)(h) of the Accord Act grants the Governor in Council, not the Board, the authority to authorize "the discharge, emission or escape of petroleum ... in such quantities, at such locations, under such conditions and by such persons as may be specified in the regulations." ${ }^{80}$ In similar fashion, it is the Governor in Council that is given specific authority to prohibit the "introduction into the environment of substances, classes of substances and forms of energy."81 Nowhere in the Accord Act and its associated regulations is the Board given clear authority to establish a substantive discharge regime on its own initiative and apart from the unspecific criteria enunciated in the regulations.

Nevertheless, the most significant difficulty with this technique lies with the statutory character of guidelines under the Accord Act and guidelines in general. As alluded to above, s. 156(1) of the Accord Act authorizes the Board to issue guidelines "in such manner as the Board deems appropriate ... with respect to the administration and application of ss. 45,142 and 143 and any regulations made under section $153 .{ }^{\text {"82 }}$ At first blush, one might assert that this broad discretion to issue guidelines supports, in some measure, the Board's present approach to the use of guidelines. Nonetheless, s. 156(2) of the Accord Act specifically establishes that "[g]uidelines and interpretation notes issued pursuant to subsection (1) shall be deemed not be statutory instruments." As Doherty J.A. in Ainsley Financial Corp. v. Ontario (Securities Commission) ${ }^{83}$

wo Accord Act, supra note 4, s. 153(1)(h). As alluded to above, no regulations to date specifically authorize operational discharges with any degree of substantive specificity. See Production Regulations, supra note 37 , ss. $49(1)$ and $51(2)$. In this respect, it is extremely unlikely that s. 51(5) of the Production Regulations, which calls upon the Chief Conservation Officer of the Board to approve an environmental protection plan where it will provide for the protection of the environment, can feasibly be seen as an express delegation of such authority, even if such delegation were permissible. 
notes, "a non-statutory instrument cannot impose mandatory requirements enforceable by sanction; that is, the regulator cannot issue de facto laws disguised as guidelines. ${ }^{.84}$

Non-compliance with the conditions of a production operations authorization can lead to sanctions under the Accord Act and pursuant regulations in at least two ways. First, s. 7(2) of the Production Regulations states that "[n]o person shall carry on production operations except in accordance with the conditions of the production operations authorization." Section 199(1)(a) of the Accord Act, in turn, makes it an offence to contravene promulgated regulations. Second, s. 142(5)(a) authorizes the Board to suspend or revoke an authorization for failure to comply with, or for contravention or default in respect of a requirement subject to which an authorization or licence was granted. ${ }^{85}$ This administrative sanction may result in a further sanction under the Act. Specifically, s. 199(1)(e) of the Accord Act establishes that it is an offence to carry on or undertake an activity without an authorization or to carry on or undertake the activity "without complying with the ... requirements of such an authorization." 86

As Doherty J.A. states, "[t]here is no bright line which always separates a guideline from a mandatory provision having the effect of law." ${ }^{87}$ Correspondingly, he asserts that the focus of the analysis, when attempting to distinguish between the two, should be on the "practical effects" of a failure to comply with its tenets and the expectations of the regulatory authority with regards to its implementation. It is clear that the practical effect of failing to comply with a guideline qua authorizations condition could evoke the Board's sanction powers. Justice Doherty states, in this vein, that "[ $t]$ he threat of sanction for non-compliance is the essence of a mandatory requirement." 88 Moreover, the Board's expectations as to the observance of the guidelines is evidenced by, inter alia, Condition 15 of the Development Plan Decision Report of the Sable Offshore Energy Project. ${ }^{89}$ In this respect, Condition 15 states:

The Proponents shall ... comply with any additional draft regulations, standards and guidelines that may be developed in the future and adopted by the Board. Such draft regulations, standards or guidelines may be revised from time to time and, if adopted by the Board, the revised version shall apply and shall supersede any earlier versions, upon notice being given to the Proponents. ${ }^{90}$

This case, it should be noted, was not judicially considered in Petro-Canada. This is likely due to the close proximity of the two judgments in time. Petro-Canada was heard from 10-12 April 1995, while the judgment in Ainsley, supra note 83 was delivered on 21 December 1994.

Accord Act, supra note 4, s. 142(5)(a).

Accord Act, ibid., s. 191(1)(e).

Ainsley, supra note 83 at 7.

lbid. at 8.

Supra note 49.

Ibid. at 34. Condition 15 also holds that the Proponents "shall comply with the provisions of the following draft regulations as if they were in force with respect to the Nova Scotia offshore area: Petroleum Occupational Health and Safety Regulations - Nova Scotia (April 5, 1990 Draft) and Canada Oil and Gas Operations Regulations." 
Arguably, this Condition strongly suggests that the Board treats or would treat the guidelines as equivalent to statutory provisions. ${ }^{91}$

With regard to potential sanctions, it is important to note that the imposed conditions under attack in Petro-Canada did not, directly or indirectly, raise the issue of whether or not the imposed condition could lead to sanctions against Petro-Canada under the Newfoundland Accord Act. Rather, this case involved a judicial review of the Newfoundland Board's decision to deny an application by Petro-Canada for a declaration of a "significant discovery" at a well in King's Cove. ${ }^{92}$ Accordingly, PetroCanada sought an order of certiorari in order to have the Board's decision quashed. ${ }^{93}$ The issue of whether the Board had the authority to impose the contested requirement was clearly subordinate to issues concerning the appropriate standard of review, the applicable standard of proof and the adequacy of reasons given for the denial of the application. ${ }^{94}$

Another related difficulty with the Board's technique of linking guidelines and authorization conditions is the manner in which the authorization conditions are to mirror changes in the guidelines over time. This method of varying the content of the authorization conditions is exemplified by Condition 15 of the Development Plan approval of the Sable Project, which specifically provides that the revised versions of draft regulations, standards and guidelines shall apply and supersede any earlier versions. This approach is affirmed by CNSOPB policy, which declares that existing projects will not be "grandfathered" when regulations or standards are amended.9 Accordingly, the Board "will require that future activities be assessed against regulations or draft regulations, standards and guidelines in place when the activity occurs." 96 The difficulty with this approach lies in the potential for it to be characterized as an impermissible change to the "rules of the game."

In Petro-Canada, the applicant submitted that the condition of the drilling program authorization was imposed in a manner that changed the rules of the game after an

One might try to distinguish Ainsley by suggesting that the argument is not applicable to the instant case where one is dealing with an approval with guidelines attached to it which form part of the approval, as opposed to simply complying with guidelines in the absence of an approval. This argument, however, is somewhat deficient in that Ainsley itself dealt with a policy that established that the "approval" of penny-stock trades was conditional upon the provision to prospective clients of risk-disclosure statements and suitability assessments. See Ainsley Financial Corp. v. Ontario (Securities Commission) (1993), 17 Admin. L.R. (2d) 281 (Ont. Gen. Div.). Petro-Canada, supra note 69 at 202.

Ibid. While it could be argued that the unwillingness of the Board to make the declaration at issue amounts to a type of sanction, the context was clearly not prosecutorial.

Ibid. A similar problem was identified as a potential issue by the Trial Division of the Newfoundland Supreme Court in Saint John's (City), supra note 6 at para. 11. In this case, Osborn J. noted that there was no specific reference to the Newfoundland Board's ability to attach conditions to its approval of a benefits plan. Nonetheless, all counsel proceeded without questioning the Board's ability in this regard. Accordingly, the Board's legal authority to revoke an activity authorization for non-compliance was not questioned by the court.

Decision Report, supra note 49 at 34.

Ibid. [emphasis added]. 
investment had been made, since the same requirement had not been imposed for other offshore wells up to that time. ${ }^{97}$ Justice Barry rejected this submission on the grounds that there was no evidence that the contested condition had been imposed with respect to other offshore wells and that the condition had been imposed before Petro-Canada had accepted the Drilling Program Authorization and began drilling. This holding seems to suggest that a condition introduced after an authorization had been issued, by means of an amendment to a guideline or otherwise, would be impermissible. ${ }^{98}$ It is important to note that this difficulty would arise even if the Board's quasi-regulatory approach to the use of guidelines were found to be statutorily authorized.

The above-noted difficulties clearly put at issue the Board's ability to enforce the conditions of its production authorizations and, by extension, the Waste Treatment and Chemical Selections Guidelines. These concerns would, of course, be obviated if the standards embraced in the guidelines were translated into regulations as they would then clearly and unproblematically have the force of law. Whether this tenuous approach will be forsaken is an open question. Until then, the potential for an operator to successfully challenge the Board's authority to impose such conditions in an enforcement context remains very real and, in light of the potential environmental harms, unsettling.

\section{B. Administrative Problems}

As Boris de Jonge indicates, the Board's approach to the use of guidelines qua authorization conditions also creates administrative difficulties with respect to the potential application of s. 36(3) of the Fisheries $A c t^{99}$ to operational discharges. ${ }^{100}$ This provision states that "no person shall deposit or permit the deposit of a deleterious substance of any type in water frequented by fish." Act creates an exemption from s. 36(3) for depositions of "waste or pollutant of a type, in a quantity and under conditions authorized by regulations applicable to that water or place made by the Governor in Council under or any Act other than this Act." ${ }^{102}$ This presents at least two significant difficulties.

First, it is not clear that an operator may rely, pursuant to s. 36(4) of the Fisheries $A c t$, on an authorizations approval from the Board in relation to operational discharges such as produced water, drilling mud, or drill cuttings in light of the fact that the Board

Petro-Canada, supra note 69 at 229-30.

Unless, of course, there is express statutory authority to vary these conditions after an authorization is granted. Such authority does not appear to exist under the Accord Act, nor does it appear to be implicit. In this regard, the wording of s. 142(5)(a) of the Accord Act is illustrative. As noted above, this section provides for the suspension of an authorization for failure to comply with "a requirement ... subject to which the licence or authorization was issued." Limiting this administrative sanction to the terms upon which the authorization was granted strongly suggests that such variation is not statutorily endorsed [emphasis added].

R.S.C. 1985, c. F-14.

de Jonge, supra note 59 at 78.

Fisheries Acl, supra note 99, s. 36(3).

Ibid., s. 36(4). 
is not explicitly given the power to authorize the discharge of such materials into the marine environment under the Accord Act and associated regulations. ${ }^{103}$ As noted above, the Accord Act specifically delegates this authority to the Governor in Council. Likewise, s. 122 of the Nova Scotia Offshore Area Petroleum Drilling Regulations ${ }^{104}$ requires that operational waste material be disposed of in a manner endorsed by the Board, but does not explicitly empower the Board to authorize such discharges. ${ }^{105}$ Similarly, s. 49(1) of the Production Regulations obliges an operator to "ensure all waste material produced ... is treated, handled and disposed of in accordance with the environmental protection plan." 106 The environmental protection plan, pursuant to $\mathrm{s}$. $51(5)$, is approved solely on the basis that it "will provide for the protection of the natural environment." 107 This provision does not explicitly empower the Board to authorize discharges into marine environments. Correspondingly, it is doubtful that an operator could rely on the above regulations themselves as it is likely that they are not specific enough to satisfy the requirements of s. 36(4) of the Fisheries Act in that they do not specify the type or quantity of an authorized discharge. ${ }^{108}$

Second, it is unlikely that an operator could rely on the Waste Treatment Guidelines as applied by the Board as they do not appear to be "regulations" within the meaning of s. 36(4) of the Fisheries Act. ${ }^{109}$ As noted above, guidelines issued under the Accord Act are explicitly identified as non-statutory. In light of this and the foregoing discussion, it is highly unlikely that the guidelines could be successfully construed to be "regulations." Moreover, even if it could be successfully argued that the guidelines are "regulations," they would be regulations made by the Board. Section 36(4), however, creates an exception to s. 36(3) only with respect to regulations made by the Governor in Council under another Act. As such, the Board's authorization, however construed, would not qualify. ${ }^{110}$

In these circumstances, an operator would be advised to seek separate authorization from Environment Canada or the Department of Fisheries and Oceans with respect to the Fisheries Act. ${ }^{11}$ As de Jonge notes, it is inefficient and potentially confusing to have two or more agencies making decisions regarding the same issue. ${ }^{112}$ On another

de Jonge, supra note 59 at 79. As the Lasmo incident referred to by de Jonge indicates, this is a valid concern for offshore operators. See de Jonge, supra note 59 at 79-82.

N.S. Reg. $137 / 92$.

de Jonge, supra note 59 at 79.

Production Regulations, supra note 37, s. 49(1).

Ibid., s. 51(5).

de Jonge, supra note 59 at 81 . Put another way, it is far from certain that "protection of the natural environment" under these regulations embodies a guarantee that a contemplated discharge will not be characterized as a "deleterious substance" under s. 34(1) of the Fisheries Act, supra note 96. de Jonge, ibid. at 81 .

lbid.

Ibid. at 79 .

Ibid. at 82 . 
level, this difficulty makes the idea that the Board is acting as a "single window" with respect to the offshore development somewhat fictitious or misleading. ${ }^{113}$

\section{CONCLusion}

In sum, in order to fulfill its environmental protection mandate the CNSOPB must deal directly with the specific ecological dangers posed by the systemic operational discharges associated with the production of offshore oil and gas. Among the operational discharges with potentially significant environmental effects are drill cuttings, drilling muds and produced water. In a general sense, operational discharges are addressed under the "spills" provisions of the Accord Act, which creates specific penalties for contravening the $A c t$ and associated regulations. Use of these penalty provisions, however, has not been pursued by the Board to date. The Board has instead preferred to rely on consultative measures and the use of "mandatory" guidelines and authorizations conditions to ensure satisfactory operational practices.

The approval process for offshore oil and gas development involves general and specific authorizations. At the preliminary Development Plan Application stage, an operator must submit an environmental impact statement, which may contain a fullfledged environmental protection plan or the basic elements thereof. Under the Production Regulations, the implementation of an environmental protection plan is mandatory. The environmental protection plan, which must be approved by the Board, must describe the procedures in place for handling and disposing of waste materials within approved limits and provide for compliance monitoring. The Production Regulations, however, do not themselves establish specific substantive limits with respect to the composition of discharged materials. Rather, the Board uses guidelines to establish the minimum standards of the discharge regime.

The two principal guidelines employed in this regard are the Waste Treatment Guidelines and the Chemical Selection Guidelines. These guidelines, which generally determine the content of the conditions attached to specific work authorizations, set substantive criteria for operational discharges and envision both environmentalcompliance and effects-monitoring programs. Taken as a whole, the discharge regime established under the Accord Act by the Board is one that relies primarily on the internal environment-management systems of the operator to ensure compliance with the applicable standards. Nonetheless, where these systems are flawed the Board may resort to administrative sanctions and prosecutions under the Accord Act. The potential resort to these sanctions is rendered problematic, however, by the legal and administrative problems associated with the attempt to create guidelines with mandatory effects.

111 These concerns, however, have been mitigated to some extent by the Memorandum of Understanding (MOU) adopted by the Board and the Department of Fisheries and Oceans in July 2001. This MOU speaks directly to coordination with respect to, among other things, operational discharges. Nevertheless, this MOU does not transform guidelines into "regulations" within the meaning ascribed to this term in the Fisheries $\mathrm{Act}$. 
Most significantly, it would seem that the manner in which the Board uses its guidelines to impose binding requirements is beyond its statutory authority. This issue was, to some extent, dealt with as a corollary issue in Petro-Canada v. CanadaNewfoundland Offshore Petroleum Board. In Petro-Canada, Barry J. held that the Newfoundland Board's authority to impose requirements other than those called for in the regulations was broad enough to allow incorporation of draft regulations by reference in the requirements of an authorization approval. This case was, however, decided in relation to a legislative context that differs in important respects from the present Nova Scotia Accord Act. Under this Act, the Governor in Council, not the Board, is given the explicit authority to incorporate standards by reference. Moreover, the guidelines under the Accord Act are expressly deemed to be non-statutory instruments. As the Ontario Court of Appeal in Ainsley Financial illustrates, nonstatutory instruments cannot impose mandatory requirements that are enforceable by sanction. In other words, a regulator cannot issue de facto laws disguised as guidelines. Both the practical effects of non-compliance and the ostensible expectations of the Board demonstrate that the guidelines are mandatory in nature. Another difficulty relates to the manner in which changes to the guidelines are to vary the conditions of authorizations approvals, even after such approvals have been issued. This approach may constitute an impermissible changing of the "rules of the game." These concerns clearly put the Board's authority to enforce the procedural and substantive standards embodied in the guidelines at issue.

The Board's technique of creating "mandatory" guidelines through its authority to issue authorizations conditions also creates administrative problems, particularly in relation to s. 36(3) of the Fisheries Act. First, it is unlikely that an operator can rely on an authorizations approval to fall within the exemption created by s. 36(4) of the Fisheries $A c t$, as the Board is not specifically empowered to authorize discharges under the Accord Act and the guidelines themselves do not qualify as "regulations" under s. 36(4). As a result, an operator would be obliged to seek a separate authorization from Environment Canada to alleviate fears of prosecution under s. 36(3) of the Fisheries Act. I suggest that such difficulties cast doubt on the efficiency and clarity of the regime governing operational discharges and offshore development in general. 